\title{
Terrorism and Just War
}

\author{
Michael Walzer
}

Published online: 4 August 2006

(C) Springer Science + Business Media B.V. 2006

I will begin by arguing that just war theory helps us understand the wrongfulness of terrorism, and then I will do two things with this argument - first, consider the choice of terror as a political strategy, and then worry about some of the problems of combating it. What can go wrong in the 'war' against terrorism, and is just war theory equally helpful in thinking about this 'war' - where the scare quotes are always necessary?

Terrorism is the random killing of innocent people, in the hope of creating pervasive fear. The fear can serve many different political purposes, none of which, as I will argue later on, need figure in the definition (it's easy to imagine a terrorist organization, as it might be portrayed by Franz Kafka, say, that has no purpose at all). Randomness and innocence are the crucial elements in the definition. The critique of this kind of killing hangs especially on the idea of innocence, which is borrowed from just war theory - and often misunderstood. 'Innocence' functions in the theory as a term of art; it describes the group of noncombatants, civilians, men and women who are not materially engaged in the war effort. These people are 'innocent' whatever their government and country are doing and whether or not they are in favor of what is being done. The opposite of 'innocent' is not 'guilty,' but 'engaged.' Disengaged civilians are innocent without regard to their personal morality or politics.

But why are all civilians immune from attack, while soldiers are collectively at risk? According to the rules of jus in bello, once the fighting has begun, it is entirely legitimate to kill soldiers at random, as they come within range, so to speak, and it is legitimate to try to terrorize the ones who never come within range. And yet, a lot of soldiers are not actual combatants; they serve behind the lines; they are involved in transportation, the provision of food, the storing of supplies; they work in offices; they rarely carry weapons. And no soldiers are always combatants; they rest and play, eat and sleep, read newspapers, write letters. Some of them are in the army by choice, but some of them are there unwillingly; if

\footnotetext{
M. Walzer $(\bowtie)$

School of Social Science, Institute for Advanced Study, Einstein Drive, Princeton, NJ 08540, USA

e-mail: walzer@ias.edu
} 
they had been given a choice, they would be doing something else. How can they all be subject to attack simply because they bear the name, and wear the uniform, of a soldier? Why doesn't innocence, as a term of art, describe some of them, some of the time? On the other hand, if soldiers are rightly subject to attack, all of them, all the time, if they are collectively at risk, then why can't civilians, as a class, also be legitimate targets? These civilians are members of a political community; by a clear majority, let's say, they elected a government that is waging an unjust war or is committed to a policy of oppression, and so they share responsibility for immoral, possibly criminal, acts. Why aren't the terrorists right when they say that membership and responsibility make civilians collectively vulnerable to attack?

I am going to take this question seriously despite my skepticism about the seriousness of some of the people who ask it. The answer has to do with the meaning of membership in an army and in civilian society. The army is an organized, disciplined, trained, and highly purposeful collective, and all its members contribute to the achievement of its ends. Even soldiers who don't carry weapons have been taught how to use them, and they are tightly connected, by way of the services they provide, to the actual users. It doesn't matter whether they are volunteers or conscripts; their individual moral preferences are not at issue; they have been mobilized for a singular purpose, and what they do advances that purpose. For its sake, they are isolated from the general public, housed in camps and bases, all their needs provided for by the state. In time of war they pose a unified threat.

The society of civilians is not at all like that; civilians have many different purposes; they have been trained in many different pursuits and professions; they participate in a highly differentiated set of organizations and associations, whose internal discipline, compared to that of an army, is commonly very loose. They don't live in barracks but in their own houses and apartments; they don't live with other soldiers but with parents, spouses, and children; they are not all of an age but include the very old and the very young; they are not provided for by the government but provide for themselves and one another. As citizens, they belong to different political parties; they have different views on public issues; many of them take no part at all in political life; and, again, some of them are children. Even a levee en masse cannot transform this group of people into anything like an organized military collective.

But they are a collective of another kind: They are, together with their sons and daughters in the army, a people. Whether their peoplehood is ethnic or national in character or wholly political, constituted only by their citizenship, doesn't matter here. They identify themselves as French, or Irish, or Bulgarian; they commonly share a language and a history and, in some prosaic sense of the term, a destiny. Their individual futures are closely linked, and this linkage is especially tight when their country is at war; it is central to how we think about them in wartime.

Implicit in the theory of just war is a theory of just peace: Whatever happens to these two armies, whichever one wins or loses, whatever the nature of the battles or the extent of the casualties, the 'peoples' on both sides must be accommodated at the end. The central principle of jus in bello, that civilians can't be targeted or deliberately killed, means that they will be - morally speaking, they have to be - present at the conclusion. This is the deepest meaning of noncombatant immunity: It doesn't only protect individual noncombatants; it also protects the group to which they belong. Just as the destruction of the group cannot be a legitimate purpose of war, so it cannot be a legitimate practice in war. Civilians are immune as ordinary men and women, disengaged from the business of warfare; they are also immune as members of a human community that is not a military organization. 
There is one partial exception to this immunity rule that also suggests its general strength. If a country fights an unjust war, and is defeated, it can be forced to pay reparations to its victims, and this burden will be distributed through the tax system to all its citizens, whatever their role in the war or their views about the war. But this collective financial burden is the only one we allow; we would not impose forced labor on the citizens of the defeated state; and we would certainly not kill them simply because of their citizenship. Only individuals charged with specific war crimes can be brought to trial and, possibly, executed. All the others retain their individual and group immunities: It is both right and good that their lives continue and that their political or national community survives.

Terrorists attack both these immunities. They devalue not only the individuals they kill but also the group to which the individuals belong. They signal a political intention to destroy or remove or radically subordinate these people individually and this 'people' collectively. Hence, while all terrorists are murderers, all murderers are not terrorists. Most murderers intend to kill specific people; terrorists kill at random within a specific group of people. The message they deliver is directed at the group: We don't want you here. We will not accept you or make our peace with you as fellow-citizens or partners in any political project. You are not candidates for equality or even co-existence.

This is most obviously the message of nationalist terror, aimed at a rival nation, and of religious terror, aimed at infidels or heretics. State terror is also most often focused on a collective that is thought to be oppositional or potentially so-sometimes an ethnic group, sometimes a socio-economic class: The Tatars, the Kurds, the kulaks, the urban middle class, anyone with a college education, and so on. But sometimes state agencies use random killing, 'disappearances,' arrests, and torture to terrorize the whole population of their country. Now it's not massacre or removal that is being signaled, but tyranny, that is, radical subordination. In fact, tyranny and terror are always closely connected. Tyrants rule by terror, as Aristotle first pointed out. And when terrorists-out-of-power seize power, they are likely to rule in the same way; intimidation, not deliberation, is their modus operandi. Edmund Burke was not right about the French Revolution as a whole or about the political doctrines that inspired it, but he was certainly right about some of the revolutionaries - the ones who launched the Terror: "In the groves of their academy, at the end of every vista, you see nothing but the gallows."

But isn't terror sometimes a more modest strategy, aimed only at changing the policy of a government? The innocent people targeted are the people this government is supposed to protect, and the message is that they will be at risk until the government surrenders or withdraws or concedes some set of demands. Once that happens, the killing will stop - so the terrorists say - and the innocent people, those of them who are still alive, won't be forced to abandon their homes or submit to a tyrannical regime. Consider the American use of nuclear weapons against Japan in 1945: This was surely an act of terrorism; innocent men and women were killed in order to spread fear across a nation and force the surrender of its government. And this action went along with a demand for unconditional surrender, which is one of the forms that tyranny takes in wartime. In the end, the US did not insist on unconditional surrender, and the occupation of Japan was not a permanent subordination of the Japanese people to American power. But this only means that the message terrorists send is not always acted out later on. There can't be any doubt that the destruction of Hiroshima and Nagasaki implied, at the moment the bombs were dropped, a radical devaluation of Japanese lives and a generalized threat to the Japanese people.

Sometimes, perhaps, terrorists do have limited purposes - though it might be better to say that sometimes political militants with limited purposes are called terrorists but don't 
quite fit the definition. Consider the case of the Irish Republican Army. The aim of its members is to reunite Ulster with Eire, and they are prepared, officially at least, to accept Ulster Protestants as a minority in a unified Ireland. Perhaps for that reason, their killings have not been random. They have attempted to kill political leaders, punish particular individuals for 'collaboration' with the British, attack buildings that symbolize the power structure. And they have mostly given warnings in advance of their attacks, so as to allow people to get out of the way. I don't mean to justify IRA violence, only to suggest that if we want to condemn it, 'terrorism' may not be the right word to use. It isn't, after all, the only negative term in our moral vocabulary.

But in all those cases where violence is random, directed against innocent men and women, its victims have good reason to be skeptical about claims that the terrorists have a limited agenda. From the perspective of the victims, which is morally very important, terror is a totalizing practice. Random murder implies universal vulnerability, and the implication is often realized in practice. Stalinist terror, to take an obvious example, was not designed 'to win the class struggle in the countryside' by threatening the Kulaks; it was designed to get rid of the Kulaks. Algerian terrorists probably intended what they achieved - the removal of Europeans from Algerian soil (they had considerable help from the Europeans). Palestinian terrorists have been remarkably honest about their intentions; they don't claim to have limited purposes, though the claim is sometimes made on their behalf. Perhaps Basque terrorists would settle for a state of their own; they don't intend the destruction of Spain. But they may well intend the ethnic (and ideological) cleansing of the Basque country. Similarly, revolutionary terrorists like the various 'Red Armies' of the 1970s presumably would have stopped killing capitalists once the capitalist system had fallen. On the other hand, they might have tried to purge their country of its corrupt and now counter-revolutionary bourgeoisie. It seems best to take seriously the signal that terrorists send.

Of course, terrorists don't want to be identified and judged by the signal they send but rather by the goals they announce - not the destruction, removal, or radical subordination of a people but rather victory in a just war, or national liberation, or the triumph of their religion. And why shouldn't we identify them first of all by reference to their stated ends rather than to the means they employ? I have often heard it said that a war against terrorism makes no sense, since terror is an instrument, not a full-scale politics like, say, communism or Islamic radicalism. But surely one of the most important reasons (not the only one) for opposing communism and Islamic radicalism is that these ideologies have served, in the real world, to inspire and justify terrorism. The instruments one chooses are often morally defining - as in the case of the members of Murder, Incorporated, say, or the Mafia, whose long-term end, making a lot of money, is shared with many other people and entirely acceptable in a capitalist society. No doubt, the goals of criminal gangs fail to justify the means they choose, but, what is equally important, the goals don't serve to identify the actors. Members of the Mafia may think of themselves as businessmen, but we rightly call them gangsters. Similarly, men and women who bomb urban residential areas, or organize massacres, or make people 'disappear,' or blow themselves up in crowded cafes may think of themselves as political or religious militants or as public officials and civil servants, but we rightly call them terrorists. And we oppose them, or we should oppose them, because they are terrorists.

If we name terrorists by their actions rather than their supposed goals, we are then free to support the goals - if we think them just - and even actively to pursue them in non-terrorist ways. We can support the US war effort against Japan even while we oppose the bombing of Hiroshima and Nagasaki. We can work for Algerian independence even while we oppose 
FLN terrorism. We can call for Palestinian statehood, while condemning the groups that attack Israeli civilians. A decent politics often requires a two front campaign - against oppression and occupation, as in the last two cases, and also, simultaneously, against murder.

I don't believe that terrorism can ever be justified. But I also don't want to defend an absolute ban. "Do justice even if the heavens fall" has never seemed to me a plausible moral position. In rare and narrowly circumscribed cases, it may be possible, not to justify, but to find excuses for terrorism. I can imagine myself doing that in the hypothetical case of a terrorist campaign by Jewish militants against German civilians in the 1940s - if attacks on civilians had been likely (in fact they would have been highly unlikely) to stop the mass murder of the Jews. The argument from extremity might work in truly extreme circumstances, but we have to be very careful here, for terrorism, as I have been insisting, threatens mass murder even when it doesn't reach that far. In fact, I don't know of any actual terrorist campaign that can be excused in this way - despite the common claim of desperation. The standard excuses don't work. Actual terrorists threaten mass murder in order to oppose or, better, with a pretense of opposing, something less. And most often they have the totalizing intentions that their actions signal.

This is the wrong of terrorism: The murder of the innocent and the creation of a devalued collective, a group of men and women who have been deprived of the right to life or, alternatively, of the right to live where they are living. They have been denied what may well be the most important of the Four Freedoms proclaimed by Roosevelt and Churchill in 1943: Freedom from fear. It is the extension of violence or the threat of violence from individuals to groups that is the special feature of terrorism: Men and women are targeted because of their membership - because they are Japanese, or Protestants in Northern Ireland, or Muslims in Gujarat, or Jews in Israel. It is who you are, not what you are doing, that makes you vulnerable; identity is liability. And that's a connection that we are morally bound to resist.

\section{II}

Terror is a strategy that has to be chosen from a fairly wide range of possible strategies. It is always a choice. For many years, I have been urging that when we think about terrorism we have to imagine a group of people sitting around a table, arguing about what ought to be done. We don't have minutes of those meetings, but we have descriptions of them, and we know that they have taken place in all the cases of terrorist activity. We also know that some people around the table have argued against the choice of terror. Terrorism is not the general will of Irish Catholics or Algerians or Palestinians or Americans (there were leading figures in the US government and army who opposed the use of the atomic bomb in 1945); it isn't the necessary product of a religious or political culture. Just as 'Asian values,' as Amartya Sen has insisted, don't mandate opposition to human rights, so Irish or Algerian or Palestinian or American values don't require the acceptance of terrorism. That is a decision supported by some, opposed by others.

I suppose that the arguments are more often prudential than moral, but I don't believe that the people sitting around the table are 'realists' who simply seize political opportunities or are driven by military necessities. That is the standard view in political science and perhaps in politics generally, and on this view moral justification is nothing but a façade, hastily erected after the crucial choices have been made. Sometimes, perhaps, 'realism' is an accurate description of what happens in the 'real world,' but I want to suggest - 
provocatively, I hope, but also realistically - that sometimes just the opposite is true: Strategic arguments about what is possible or necessary are a façade behind which militants and officials act out their deepest political/moral convictions. Sometimes strategy is a disguise for morality (or immorality).

Consider the British decision to bomb German cities. In the early 1940s, British politicians and generals, sitting around a table, debated strategic bombing policy. Should the goal of the RAF be to kill as many German civilians as possible, so as to terrorize the enemy and shut down the economy, or should the pilots aim only at military targets? The debate was conducted, as far as I can tell from the available memoirs and histories, entirely in the language of strategy; the principle of noncombatant immunity was never mentioned. What were the probabilities of hitting military targets, given the navigational and aiming devices then available? What losses would the air force suffer if it flew by day so as to aim (a little) more precisely? What were the likely effects of bombing urban residential areas on civilian morale and then on the production and delivery of military supplies? Outside the government, a few people raised moral questions about bombing policy; inside, it was as if there was a ban on moral talk: There's no-one here but us realists! But if you look at the years after the war, it turns out that the people who favored bombing residential areas in, say, 1943 were, later on, advisors and office-holders in Tory governments where they continued to defend tough and 'realistic' decision-making, and the people who opposed it were on the left, working for Labor governments or the Campaign for Nuclear Disarmament and, often, making the moral arguments they didn't make during the war. Surely their strategic arguments in 1943 were driven in part by their repressed political/ moral convictions - not only by their views on the 'necessity' of killing civilians, but also by their views on the rightness or wrongness of such killing. After all, strategists commonly work from inadequate and uncertain information; their predictions are cast in very rough probabilities; they can easily go either way, and they seem to go, or often to go, the way the people making them (or the people for whom they are made) want them to go.

So, when terrorists tell us that they had no choice, there was nothing else to do, terror was their last resort, we have to remind ourselves that there were people around the table arguing against each of those propositions. And we also have to recognize that strategic considerations are not the sole, possibly not the most important, factor shaping these arguments. The overall politics and morality, the worldview, of the participants is also a factor. They are in fact answering questions like these: Do they acknowledge the human value of their enemies? Are they prepared for a compromise peace? Can they imagine a future state in which they share power but do not rule? This is what is actually at stake around the table, and we can see the wrong of terrorism reiterated in the negative answers that come from its advocates.

\section{III}

Once the decision is made, and terrorists are doing their work, how should we fight against them? I am going to assume the value of doing that, and I am not going to consider here efforts to do something else under cover of the 'war' against terrorism (like fight a war in Iraq). There isn't any worthy political cause that can't be exploited for unworthy and unrelated purposes, but my subject here is the cause, not the exploitation. I am also not going to try to describe the necessary political response to terror. I take it for granted that a political response is necessary, but 'fighting' is also necessary. The first answer to the question about how to fight is simple in principle, though often difficult in practice: Not 
terroristically. That means, without targeting innocent men and women. I will focus on that principle, which derives from the theory of just war - though the 'war' against terrorism is closer, as we will see, to police work than to actual combat. And so there is a second answer to the question about how to fight: Just as the police are supposed to do, we must operate within the constraints of constitutional democracy. But constitutionalism, like politics more generally, is a subject for another occasion.

In order to fight, you have to identify the enemy, so it is very important to say at the outset that the people the terrorists claim to represent are not themselves complicit in the terror. Whatever their emotional connection or disconnection (and we know that they are often strongly connected), they are not material supporters; they fit my description of the civilian collective. The terrorists do have material support, but their supporters are particular men and women, not the people generally. At the end of the 'war' against terrorism, as at the end of any other war, the people generally will have to be accommodated. The terrorists collectivize the guilt of the other side, insisting that every single person is implicated in the war or the oppression. The anti-terrorists must collectivize in the opposite way, insisting on the innocence of the people generally. Like the police, again, they have to look for the particular individuals who are planning, providing material support for, or actually carrying out terrorist operations. That search is more difficult than the search for legitimate targets in 'ordinary' warfare. There are indeed terrorist organizations, which sometimes look like criminal gangs, sometimes like enemy armies, but are probably best thought of as different from both of these. In any case, however they identify themselves, they are not the same as 'the people.'

It is a moral and political mistake, then, to engage in collective punishments destroying the family home where a suicide bomber lived, for example, as the Israelis have done, on the assumption that the family supported the bomber or could have prevented the bombing. That might sometimes be true, but it is often untrue (despite the statements family members are forced to issue after the event). In domestic society, the police are not allowed to act like that, demolishing the homes of Mafia relatives, say, because they live off the family business; nor should armies or 'special forces' be allowed to do that either. If a particular relative is complicit in the crime, then the anti-terrorists have to find some way to apprehend and punish that person - not the family, the village, or the urban neighborhood. Collective punishment treats people as enemies who may be as different from one another (in their politics, for example) as were the people in the café or on the bus that the suicide bomber attacked. And it is to the advantage of the anti-terrorists that those (political) differences be brought into the open, not suppressed.

The terrorists hold that there is no such thing as 'collateral' or, as the dictionary says, secondary damage. All damage for them is primary, and they want to do as much damage as they can: The more deaths, the more fear. So anti-terrorists have to distinguish themselves by insisting on the category of collateral damage, and by doing as little of it as they can. The same rules of jus in bello apply to the 'war' against terrorism as to war in general: Soldiers must aim only at military targets and they must minimize the harm they do to civilians. I don't believe that the doctrine of 'double effect,' as it is usually understood, adequately describes what is required here. It isn't enough that the first effect, the damage to military targets, is intended and the second one, the harm to civilians, is unintended. The two effects require two intentions: First, that the damage be done and, second, that the harm be avoided. What justice demands is that the army take positive measures, accept risks to its own soldiers, in order to avoid harm to civilians. The same requirement holds for anti-terrorists - holds more strongly, I think, insofar as it is mostly police rather than soldiers who are at work in this 'war' (or, the soldiers are doing police 
work), and we impose much higher standards of care for civilians on the police than we do on armies in combat.

This need for care also governs the practice that has come to be called 'targeted killing.' It is the Israelis who made this practice famous, but I am going to look at an American example. First, though, a general word. The killing of the political leaders of the enemy state is ruled out by just war theory, as it is by international law, because of the assumption that the war will end, and should end, with a peace agreement negotiated with those same leaders, who are taken to be representative figures. Not many people would have opposed the assassination of Adolph Hitler, but that was (in part) because we had no intention of negotiating with him. But this argument applies only to political leaders, the heads of the civilian collective; it doesn't apply at all to army officers, who are part of a military collective.

We should probably try to make this same distinction with regard to terrorist organizations, even when it is blurred or non-existent in fact. In Ireland, the political party, Sinn Fein, managed to separate itself from the IRA - an 'army' whose members (whether terrorists or not) were vulnerable to arrest or attack in a way that the politicians were not. If the separation was a pretense, as the British claimed for a long time, it was a useful pretense, as they acknowledged in the end when they negotiated with the leaders of Sinn Fein - who were by then in a tense relationship with IRA militants. It is harder to figure out how to deal with organizations that hardly bother to pretend that they have separate political and military 'arms,' like Hamas in Palestine, where the claim to separation is made only after an Israeli attack and then forgotten. Still, it might be prudent to support the pretense in the hope that it will one day take on some reality and open a path to negotiation. But this is prudence, it seems to me, not a moral requirement (except insofar as political leaders ought to be prudent). In any case, the vulnerability of military leaders is clear. If a couple of British commandos in World War II had crossed German lines in North Africa (or if a couple of German commandos had crossed British lines), made their way to army headquarters, and killed a colonel, a brilliant tactician, who was planning, but wasn't going to be engaged in, the next tank attack, that would have been a 'targeted killing,' but not a wrongful assassination.

Now consider the case of the five Al Qaeda militants (so they were described by US officials) traveling in a van in the Yemini desert, who were killed by a Hellfire missile late in 2001. Had the same attack taken place in Afghanistan, it would have been an act of war. Assuming that the people killed were correctly identified, we would not have thought the attack wrong or even problematic. It is part of the awfulness of war that people actively engaged on the other side can legitimately be killed without warning. Sometimes it is possible to offer them a chance to surrender but often, in night raids, ambushes, and air attacks, for example, it isn't possible.

Now imagine that the same Hellfire attack on the same people in the same van had taken place not in Afghanistan but on a street in Philadelphia. It would not be an act of war, and it would not be legitimate. We would be horrified; the attack would be a political crime, and we would look for the officials responsible. In Philadelphia, the (suspected) terrorists would have to be arrested, arraigned, provided with lawyers, and brought to trial. They could not be killed unless they were convicted - and many Americans, opposed to capital punishment, would say: Not even then.

Yemen is somewhere between Afghanistan and Philadelphia. It isn't a war zone, but it also isn't a zone of peace - and this description will fit many, not all, of the 'battlefields' of the 'war' against terrorism. In large sections of Yemen, the government's writ doesn't run; there are no police who could make the arrests (14 soldiers had already been killed in 
attempts to capture the $\mathrm{Al}$ Qaeda militants) and no courts in which prisoners could expect a fair trial. The Yemini desert is a lawless land, and lawlessness provides a refuge for the political criminals called terrorists. The best way to deal with the refuge would be to help the Yemini government extend its authority over the whole of its territory. But that is a long process, and the urgencies of the 'war' against terrorism may require more immediate action. When that is true, if it is true, it doesn't seem morally wrong to target Al Qaeda militants directly - for capture, if that's possible, but also for death. Yemen in this regard is closer to Afghanistan than to Philadelphia.

But there are two moral/political limits on policies of this sort, and the limits are critically important because governments, once they learn to kill, are likely to kill too much and too often. The first limit is implied by the word 'targeted.' We have to be as sure as we can be, without judge or jury, that the people we are aiming at are really Al Qaeda militants or, more generally, that they are engaged in planning and carrying out terrorist attacks. Targets have to be identified, and the work of identification must be careful and precise.

The second limit is even more important. We have to be as sure as we can be that we are able to hit the targeted person without killing innocent people in his (or her) vicinity. Here I think that we have to adopt standards that are closer to Philadelphia than to Afghanistan. In a war zone, collateral damage cannot be avoided; it can only be minimized. The hard question in war is what degree of risk we are willing to accept for our own soldiers in order to reduce the risks we impose on enemy civilians. But when the police are chasing criminals in a zone of peace, we rightly give them no latitude for collateral damage. In the strongest sense, they must intend not to injure civilians - even if that makes their operation more difficult and even if the criminals get away.

That seems to me roughly the right rule for people planning targeted killings. Like the police, they are not actually engaged in a battle; they plan their attack in advance and they can call it off if they discover, say, that their target is holding a child on his lap (as in Albert Camus's play 'The Just Assassins'), or has moved into a crowd, or is sitting in an apartment that isn't empty - as it was expected to be. They can't avoid imposing some degree of risk on innocent people, and the risks will certainly be greater than those imposed by police in a city at peace, but we must insist on a strenuous effort to minimize the risks. The American attack in the Yemini desert may have met this standard; I don't know enough about the people killed, or about other people in the vicinity, or about the tactical choices that had to be made, to arrive at a firm judgment. Some of Israel's targeted killings have met the standard; some almost certainly have not. A car on a busy street is not a permissible target no more than a single table in a crowded café would be. If terrorists use other people as shields, then anti-terrorists have to find their way around the shields, just as we would want the police to do. The case of the one ton bomb dropped on an apartment house in Gaza, where the target was one person but almost 20 were killed, is a paradigmatic example of what should not be done. I don't think that it could be justified even by wartime rules of 'taking aim.' But maybe this attack was not a case of 'targeted' killing; reading newspaper accounts, it is difficult to avoid the sense that its intent was to terrorize a civilian population whose members were taken, collectively, to be supporters of terrorism.

When killing takes precedence over targeting, the anti-terrorists look too much like the terrorists, and the moral distinction that justifies their 'war' is called into question. The same thing happens in domestic society when the line between police and criminals is blurred by the brutality or corruption of the police. But it is important to stress that when that happens, we defend the line as best we can by criticizing and reforming the police; we don't join the criminals. Similarly, whatever goes wrong in the 'war' against terrorism doesn't affect the wrongness of terror. In fact, it confirms the wrongness: What we learn is 
that we have to condemn the murder of innocent people wherever it occurs, on both sides of the line.

This condemnation works best, it seems to me, if we start from just war theory with its recognition of non-combatant immunity. But as the last part of this essay should have made clear, we can't stop with just war theory. We need to maneuver between our conception of combat and our conception of police work, between international conflict and domestic crime, between the zones of war and peace. Jus in bello represents an adaptation of morality to the circumstances of combat, to the heat of battle. We may need further adaptations, to the circumstances of terror. But we can still be guided, even in these new circumstances, by our fundamental understanding of when fighting and killing are just and when they are unjust. 